Article

\title{
In Situ Effectiveness of Alkaline and Cementitious Amendments to Stabilize Oxidized Acid-Generating Tailings
}

\author{
Abdellatif Elghali *(D), Mostafa Benzaazoua *(D), Bruno Bussière and Thomas Genty \\ Research Institute on Mines and Environment (RIME), Université du Québec en Abitibi Témiscamingue, \\ 445 Boul. Université, Rouyn-Noranda, QC J9X 5E4, Canada; Bruno.bussiere@uqat.ca (B.B.); \\ thomas.genty@uqat.ca (T.G.) \\ * Correspondence: abdellatif.elghali@uqat.ca (A.E.); Mostafa.benzaazoua@uqat.ca (M.B.);

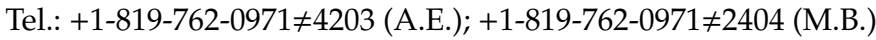

Received: 27 March 2019; Accepted: 18 May 2019; Published: 22 May 2019

\begin{abstract}
This study investigates the effectiveness of alkaline and cementitious additives in the in situ stabilization of localized acid-generating tailings from a closed gold mine in Abitibi-Témiscamingue, Québec (Eagle/Telbel mine site). Five field cells (including one control) were constructed and equipped with mechanisms for collecting vertical water infiltration and surface runoff. The five cells included: (C1) Control cell; (C2) $5 \mathrm{wt} \%$ limestone amendment; (C3) $10 \mathrm{wt} \%$ limestone amendment; (C4) $5 \mathrm{wt} \%$ half ordinary Portland cement and half fly ash amendment; and (C5) $5 \mathrm{wt} \%$ ordinary Portland cement amendment. The control cell showed an acidic behavior $(\mathrm{pH}<4.5)$ with variable concentrations of Fe, $\mathrm{Al}, \mathrm{Zn}$, and $\mathrm{Cu}$. The amendments were used to neutralize the acidic leachates and decrease dissolved metal concentrations. Leachates from surface runoff samples of amended cells were less loaded with metals compared to samples of vertical infiltration. All amendment formulations increased the $\mathrm{pH}$ of the leachates from approximately 4 to circumneutral values. Furthermore, metal and metalloid concentrations were greatly limited, except for $\mathrm{Cr}$ and As for the carbonate-based amendments. Metal(-oid) stabilization was successfully achieved using the different amendment formulations, with the exception of $\mathrm{C} 2$, which still released As.
\end{abstract}

Keywords: acid mine drainage; alkaline amendments; cementitious amendments; kinetic testing; Joutel mine

\section{Introduction}

In Canada, environmental regulations require restoration and stabilization of tailings and effluents before the final closure of mine sites. The stabilization of acid-generating tailings and contaminants released from oxidized tailings can be achieved using stabilization/solidification (S/S) techniques. Such techniques consist of adding amendments, such as alkaline materials, cementitious materials, and/or industrial sub-products, to mine wastes [1-14]. Mining amendments can be divided into two categories, depending on the objective of the amendments: (i) Alkaline amendments, which are used for increasing the neutralization potential of acid-generating tailings [15-17], and (ii) cementitious amendments, which are used for the impermeabilization/solidification of acidic tailings, but can also increase the neutralization potential [18-23].

Alkaline amendments were successfully used to control and neutralize acid mine drainage under laboratory conditions during kinetic tests $[1,8,11,24-27]$. Limestone is one of the most commonly used materials in alkaline amendments. The dissolution of alkaline amendments under acidic conditions increases the alkalinity of leachates and reduces the mobility of contaminants through mechanisms 
including: (i) Precipitation of low-solubility iron oxyhydroxides; (ii) co-precipitation in and adsorption on oxyhydroxides [11,28-31]; (iii) sulfide surface passivation, which inhibits oxygen diffusion to and from reactive sulfide cores [32-35]; and (iv) reduction of bacterial activity under circumneutral conditions [36-38]. Other materials that have successfully been used as alkaline amendments include red mud bauxite and cement kiln dust [11,12,39,40].

Cementitious amendments are used to solidify hazardous wastes and contaminated soils $[7,20,41,42]$. Cementitious amendments can reduce the contaminant mobility by the same mechanisms as alkaline amendments. However, the application of this technique allows for the solidification of reactive grains and ensures the physical trapping of contaminants (i.e., fixation). Moreover, the cementation of tailings leads to: (i) Physical encapsulation of mobile contaminants by increasing the cohesive properties of the mixture and (ii) improvements to the cohesion and the long-term impermeability of the tailings, which reduce available reactive surface area $[4,7,20,22,23,42-45]$. Various materials have successfully been used as cementitious additives for these purposes, although ordinary Portland cement (OPC) is the most common. In some cases, industrial sub-products, such as fly ash (FA), slag, lime, and cement kiln dust, have been used to partially replace OPC in cemented paste backfills [1,3,5,44,46-52].

In this study, limestone, fly ash, and ordinary Portland cement were tested at the former Eagle/Telbel mine site, which is now referred to as Joutel mine. The main objective of this study was to test the in situ effectiveness of these materials to stabilize acid-generating tailings. To accomplish this, five experimental cells were constructed and equipped with two types of water collectors, one for vertical infiltration and one for surface/subsurface runoff. This instrumentation allowed for time-series measurements of the chemical compositions of drainage waters, as well as calculations of the two main components of the water balance.

\section{Materials and Methods}

\subsection{Joutel Mine Site}

Joutel is a closed gold mine site located at the north of Abitibi-Témiscamingue (Québec, Canada). Operations at the mine took place between 1974 and 1994. The gold was associated with a sulfidic deposit that contained mainly pyrite, as well as traces of pyrrhotite, chalcopyrite, sphalerite, and galena. Gold was extracted using sulfide bulk flotation, followed by cyanidation. Ore treatment produced finely ground tailings that were deposited over 120 ha in a tailings storage facility (TSF) [53]. The TSF is divided into two zones: The northern zone, which is older and relatively elevated, and the southern zone, which is younger [54].

\subsection{Amendments Formulation}

Both alkaline and cementitious amendments were tested in in situ experimental cells. The alkaline amendments consisted of limestone. Two formulations were tested based on preliminary laboratory tests, i.e., $5 \mathrm{wt} \%$ and $10 \mathrm{wt} \%$ limestone. The amendment was mixed in situ with oxidized tailings and then deposited in the field cells. The limestone used in this study had a maximum particle size of $6.25 \mathrm{~mm}$ to ensure a mixture of fine and coarse particle sizes that would provide both short- and long-term reactivity. Calculations of the amount of limestone needed to neutralize the oxidized tailings were based on the neutralization potential (NP) and acid-generating potential (AP) of the limestone and the reactive tailings, as expressed in Equation (1):

$$
\% R=100 \times \frac{\left(\mathrm{NP}_{\text {tailings }}-\left(f \times \mathrm{AP}_{\text {tailings }}\right)\right)}{\left(f \times \sum_{i=1}^{n} X_{i} \times \mathrm{AP} i\right)-\left(\sum_{i=1}^{n} X_{i} \times \mathrm{NP}_{i}\right)}
$$

where $\mathrm{NP}_{\text {tailings }}$ is the neutralization potential of the mine tailings; $\mathrm{AP}_{\text {tailings }}$ is the acidification potential of the mine tailings; $f$ is the target $\mathrm{NP} / \mathrm{AP}$ ratio; $X_{\mathrm{i}}$ is the proportion of each amendment material used (equals 1 if only one amendment is used); $\mathrm{AP}_{\mathrm{i}}$ is the acidification potential of the amendment 
material; and $\mathrm{NP}_{\mathrm{i}}$ is the neutralization potential of the amendment material. For the studied tailings, the calculated ratio was $\sim 8 \%$ for an NP/AP ratio of 1 .

Cementitious amendments in this study consisted of OPC and FA. The two formulations used were $1 / 2 \mathrm{OPC}+1 / 2 \mathrm{FA} 5 \mathrm{wt} \%$ and OPC $5 \mathrm{wt} \%$ at a dosage relative to the total dry weight of the tailings. The FA used in this study was taken from the Boralex thermal energy station (Senneterre, QC, Canada), which generates wood-residue thermal energy. The amendment formulations for the five cells are indicated in Table 1.

Table 1. Amendment formulations used in the field cells.

\begin{tabular}{cc}
\hline Cell & Formulation \\
\hline $\mathrm{C} 1$ & Reference (oxidized tailings) \\
$\mathrm{C} 2$ & $5 \mathrm{wt} \%$ limestone \\
$\mathrm{C} 3$ & $10 \mathrm{wt} \%$ limestone \\
$\mathrm{C} 4$ & $5 \mathrm{wt} \%(1 / 2 \mathrm{OPC}+1 / 2 \mathrm{FA})$ \\
$\mathrm{C} 5$ & $5 \mathrm{wt} \% \mathrm{OPC}$ \\
\hline
\end{tabular}

\subsection{Field Cell Construction}

Field cells were constructed in an acidic area of the Joutel TSF. The cells, which were shaped as inverted truncated pyramids, were $4 \mathrm{~m}$ wide, $4 \mathrm{~m}$ long, and $0.3 \mathrm{~m}$ deep. Only oxidized tailings were used in the cells. The tailings were homogenized in situ using a mechanical loader to avoid, as much as possible, heterogeneities in the chemical and mineralogical properties of the materials. Amendments were mixed into the tailings using the bucket of a mechanical loader (Figure S1E-H). The cells were then excavated in the TSF and linear low-density polyethylene geomembranes were installed at the base and on the sides of each cell to control exfiltration [55] (Figure S1A,B,D,F). Two systems of water collection were installed at each cell. One system collected vertical infiltration, using 5-cm PVC pipes, and the other collected surface and subsurface runoff, using a combination of 5-cm PVC pipes and a gutter (Figure S1C). Each collection system was connected to an external reservoir. The cells using binders were covered with $20 \mathrm{~cm}$ of sand as a protection layer (Figure S1I). The drains for the collection systems were installed at a $2 \%$ slope. A schematic representation of the cells is shown in Figure S2. Each cell was also equipped with an EC5 volumetric water content (VWC) probe, which obtains water content by measuring the dielectric constant of the media through capacitance/frequency domain technology. Each probe was calibrated in the laboratory, using the same material present in the field. Calibration curves are presented in the supplementary materials (Figure S3). Sampling was not possible during winter; average daily temperatures are presented in the supplementary materials (Figure S4).

\subsection{Physical, Chemical, and Mineralogical Analyses}

Grain-size distributions of the studied samples were evaluated using a laser analyzer (Malvern Mastersizer, Malvern Panalytical, Canada). Bulk chemical compositions of the samples were determined by ICP-AES (Perkin Elmer Optima 3100 RL, USA), following an $\mathrm{HNO}_{3} / \mathrm{Br}_{2} / \mathrm{HF} / \mathrm{HCl}$ digestion. Major minerals in the initial oxidized tailings were analyzed by X-ray diffraction (XRD, Bruker Ltd, Canada; Brucker D8 Advance, with a detection limit and precision of approximately 1-5\%, operating with a copper cathode, $\mathrm{K} \alpha$ radiation). Results were interpreted using the DIFFRACT.EVA software (Version 3.1, Bruker, Milton, ON, Canada) and quantified using TOPAS (Version 4.2, Bruker, Milton, ON, Canada).

Leachates collected from the cells were analyzed for $\mathrm{pH}$, Eh, and electrical conductivity (EC), using $\mathrm{pH} / \mathrm{Eh} / \mathrm{EC}$ meters, and their chemical compositions were analyzed by ICP-AES, following an addition of $2 \% \mathrm{HNO}_{3}$. Iron-sulfur $\mathrm{pH}$-Eh diagrams were calculated for the control cell and for the four cells with alkaline and cementitious amendments at $21^{\circ} \mathrm{C}$, using the Geochemist's workbench (GWB) database (student edition, Version 12.0.1, Aqueous Solutions LLC, Richmond, VA, USA). Iron and 
sulfur activities were calculated using Visual Minteq (Version 3.1, KTH, Stockholm, Sweden) based on average Fe and $\mathrm{S}$ concentrations. Then, the $\mathrm{pH}$ and $\mathrm{Eh}$ data from the different cells were projected onto the Fe-S pH-Eh diagrams.

After two years, a composite solid sample was collected from each cell. The chemical composition of these samples was analyzed using ICP-AES. The mineralogy of these samples was investigated using Quantitative Evaluation of Minerals by Scanning Electron Microscopy (QEMSCAN, FEI, Hillsboro, OR, USA). QEMSCAN is an automated mineralogy system that produces particle maps through the collection of rapidly acquired X-rays. The maps and corresponding data quantify modal mineralogy, texture, grain sizes, mineral liberation, and elemental deportment. In this study, carbonate and sulfide liberation were evaluated in order to quantify the coating of each phase and, ultimately, to determine the long-term geochemical behavior of the amended tailings (especially for the limestone amendments). Polished sections were prepared for each sample and analyzed using particle mineralogy analysis mode (PMA). Measurement resolutions varied from $2.5 \mu \mathrm{m}$ to $6 \mu \mathrm{m}$, depending on the particle-size distribution of the sample. The number of analyzed particles was approximately 47391, 78089, 43077, 41851, and 42699 for samples from C1, C2, C3, C4, and C5, respectively.

\section{Results}

\subsection{Chemical, Mineralogical, Static Test, and Physical Characterizations of Solid Samples}

Table 2 shows the results of the chemical, mineralogical, and static test, and physical characterizations of the mine tailings, limestone, OPC, and fly ash. The grain-size distribution (GSD) of the mine tailings was finer compared to the limestone, OPC, and FA. The $\mathrm{D}_{90}$, which corresponds to $90 \mathrm{wt} \%$ passing on the cumulative GSD curve, was approximately $30.5 \mu \mathrm{m}$ for the mine tailings sample, $4500 \mu \mathrm{m}$ for limestone, $46.7 \mu \mathrm{m}$ for the OPC, and $1500 \mu \mathrm{m}$ for the FA. Initial water content was about $15 \mathrm{wt} \%$ for the mine tailings sample, $6.1 \mathrm{wt} \%$ for the limestone sample, $0 \mathrm{wt} \%$ for the OPC, and $3.5 \mathrm{wt} \%$ for the fly ash. Mineralogical analyses showed that the mine tailings were highly oxidized. They were mainly composed of secondary minerals, such as goethite (22 wt \%). Carbonates and sulfides constituted about 18 and $12 \mathrm{wt} \%$ of the tailings, respectively. The limestone sample was mostly composed of calcite (76 wt \%) and dolomite (22 wt \%). The fly ash sample contained about $15.5 \mathrm{wt} \%$ calcite, $3.5 \mathrm{wt} \%$ siderite, $5.3 \mathrm{wt} \%$ quartz, and $75 \mathrm{wt} \%$ of various silicate minerals. The reconciliation of the mineralogical composition of fly ash was based only on wt \% of the crystalline phases. However, fly ash is known to contain amorphous alumina-silicate glass. Consequently, the sum of wt \% of phases was less than $100 \mathrm{wt} \%$. Chemical characterizations showed that the mine tailings sample was high in Fe (27\%), S (4.40\%), and Ca (3.7\%), confirming the mineralogical composition. The limestone sample was composed mainly of $\mathrm{Ca}(34 \%)$ and $\mathrm{Mg}(2.50 \%)$. The OPC sample contained mostly Ca (49\%), Al (2.75\%), and Fe (2.25\%). The fly ash sample contained mainly $\mathrm{Ca}(7.50 \%), \mathrm{Al}(4.75 \%)$, and Fe $(2.25 \%)$. Other elements were present as trace concentrations within the four samples and the complete chemical composition of these samples is presented in Table 2. NP values, which were determined using the Sobek method as modified by Bouzahzah et al. (2015) [56], were $183 \mathrm{~kg} \mathrm{CaCO} / \mathrm{t}$ and $880 \mathrm{~kg}$ $\mathrm{CaCO}_{3} / \mathrm{t}$ for the tailings and limestone, respectively. The AP of the tailings was $195 \mathrm{~kg} \mathrm{CaCO} / \mathrm{t}$. 
Table 2. Physical, chemical, and static test, and mineralogical characterizations of the mine tailings, limestone, ordinary Portland cement, and fly ash samples. DL = detection limit.

\begin{tabular}{|c|c|c|c|c|c|c|}
\hline Characterization & Parameter & Units & MT & Limestone & OPC & FA \\
\hline \multirow{4}{*}{ Physical characteristics } & D10 & \multirow{3}{*}{$\mu \mathrm{m}$} & 1.8 & 50 & 4.2 & 82 \\
\hline & D30 & & 4.7 & 250 & 11.3 & 180 \\
\hline & D90 & & 30.4 & 4500 & 46.7 & 1500 \\
\hline & initial water content & wt $\%$ & 15 & 6.1 & dry & 3.52 \\
\hline \multirow{17}{*}{ Chemical composition } & $\mathrm{Al}$ & \multirow{17}{*}{$\%$} & 2.02 & 0.295 & 2.75 & 4.69 \\
\hline & $\mathrm{Ca}$ & & 3.72 & 33.82 & 49.07 & 7.58 \\
\hline & $\mathrm{Mg}$ & & 0.15 & 2.350 & 1.18 & 1.05 \\
\hline & $\mathrm{Mn}$ & & 0.42 & 0.031 & 0.06 & 0.42 \\
\hline & $\mathrm{Na}$ & & 1.07 & 0.125 & 0.16 & 1.96 \\
\hline & $\mathrm{K}$ & & 0.26 & 0.245 & 0.43 & 1.85 \\
\hline & $\mathrm{Fe}$ & & 27.24 & 0.483 & 2.23 & 2.24 \\
\hline & $\mathrm{Si}^{*}$ & & 17.76 & & 7.76 & 14.82 \\
\hline & $\mathrm{Li}$ & & $\leq 0.0005$ & $\leq 0.0005$ & $\leq 0.0005$ & 0.002 \\
\hline & $\mathrm{Pb}$ & & 0.013 & $\leq 0.0005$ & $\leq 0.0005$ & $\leq 0.0005$ \\
\hline & As & & 0.091 & $\leq 0.0005$ & 0.005 & $\leq 0.0005$ \\
\hline & $\mathrm{Cr}$ & & 0.0024 & 0.004 & 0.007 & 0.006 \\
\hline & $\mathrm{Cu}$ & & $\leq 0.001$ & $\leq 0.0001$ & 0.007 & $\leq 0.0001$ \\
\hline & $\mathrm{Zn}$ & & 0.01 & $\leq 0.0055$ & 0.05 & 0.07 \\
\hline & $\mathrm{S}$ (total) & & 6.80 & 0.93 & 1.74 & 0.43 \\
\hline & S (sulfates) & & 0.27 & - & - & - \\
\hline & C & & 2.2 & - & - & - \\
\hline \multirow{2}{*}{ Static tests } & NP & $\mathrm{kg} \mathrm{CaCO}_{3} / \mathrm{t}$ & 183 & 880 & - & - \\
\hline & $\mathrm{AP}$ & $\mathrm{kg} \mathrm{CaCO}_{3} / \mathrm{t}$ & 195 & - & - & - \\
\hline \multirow{15}{*}{ Mineralogical composition } & Quartz & \multirow{15}{*}{ wt $\%$} & 27.84 & 2.07 & \multirow{15}{*}{ Not applicable } & 5.32 \\
\hline & Calcite & & 7.82 & 75.76 & & 15.51 \\
\hline & Dolomite & & 0.60 & 22.17 & & \\
\hline & Muscovite & & 1.03 & & & \\
\hline & Siderite & & 11.41 & & & 3.65 \\
\hline & Orthoclase & & 0.99 & & & 8.34 \\
\hline & Biotite & & 0.23 & & & 7.52 \\
\hline & Albite & & 12.78 & & & 20.51 \\
\hline & Gypsum & & 1.45 & & & \\
\hline & Goethite & & 22.29 & & & \\
\hline & Pyrite & & 12.22 & & & \\
\hline & Labradorite & & 0.30 & & & 22.88 \\
\hline & Chlorite & & 0.74 & & & \\
\hline & Corundum & & 0.41 & & & \\
\hline & Anhydrite & & & & & 1.83 \\
\hline
\end{tabular}

\subsection{Field Cell Monitoring}

\subsubsection{Vertical Infiltration}

Vertical infiltration leachates from the different cells showed different behaviors with respect to $\mathrm{pH}$ and EC (Figure 1A,B). Leachates from the reference cell were acidic, with $\mathrm{pH}$ values between 1.7 and 4.3. However, the leachates from the amended tailings were circumneutral, with $\mathrm{pH}$ values between 6.7 and 8.4 for $\mathrm{C} 2,7.1$ and 8.1 for $\mathrm{C} 3,6.6$ and 8.6 for $\mathrm{C} 4$, and 8.8 and 10.3 for $\mathrm{C} 5$ (Figure $1 \mathrm{~A}$ ). All amendment formulations successfully buffered the acid produced by the oxidized tailings. The acidic leachates react with the limestone and binders, which dissolve and neutralize acidity $[7,11,17,26,31,57-59]$. Eh values showed oxidizing conditions (Eh $>100 \mathrm{mV}$ ) in all five cells (Figure 1C). Electrical conductivity values (Figure 1B), which illustrate the chemical quality of the leachates, showed that leachates from $\mathrm{C} 1$ were more loaded in terms of dissolved ions. EC values for $\mathrm{C} 1$ ranged between 8 and $33 \mathrm{mS} / \mathrm{cm}$. In contrast, EC values from C2, C3, C4, and C5 were between 5 and $20 \mathrm{mS} / \mathrm{cm}, 5$ and $12 \mathrm{mS} / \mathrm{cm}$, 1 and $7 \mathrm{mS} / \mathrm{cm}$, and 2 and $5 \mathrm{mS} / \mathrm{cm}$, respectively. The cementitious amendments showed the lowest EC values compared to the control cell and limestone-amended cells; hardening of tailings, due to 
cementation processes, reduces the available surface area, which reduces the leaching rates of species from mineral surfaces $[4,7,10,20,43,52,60,61]$.

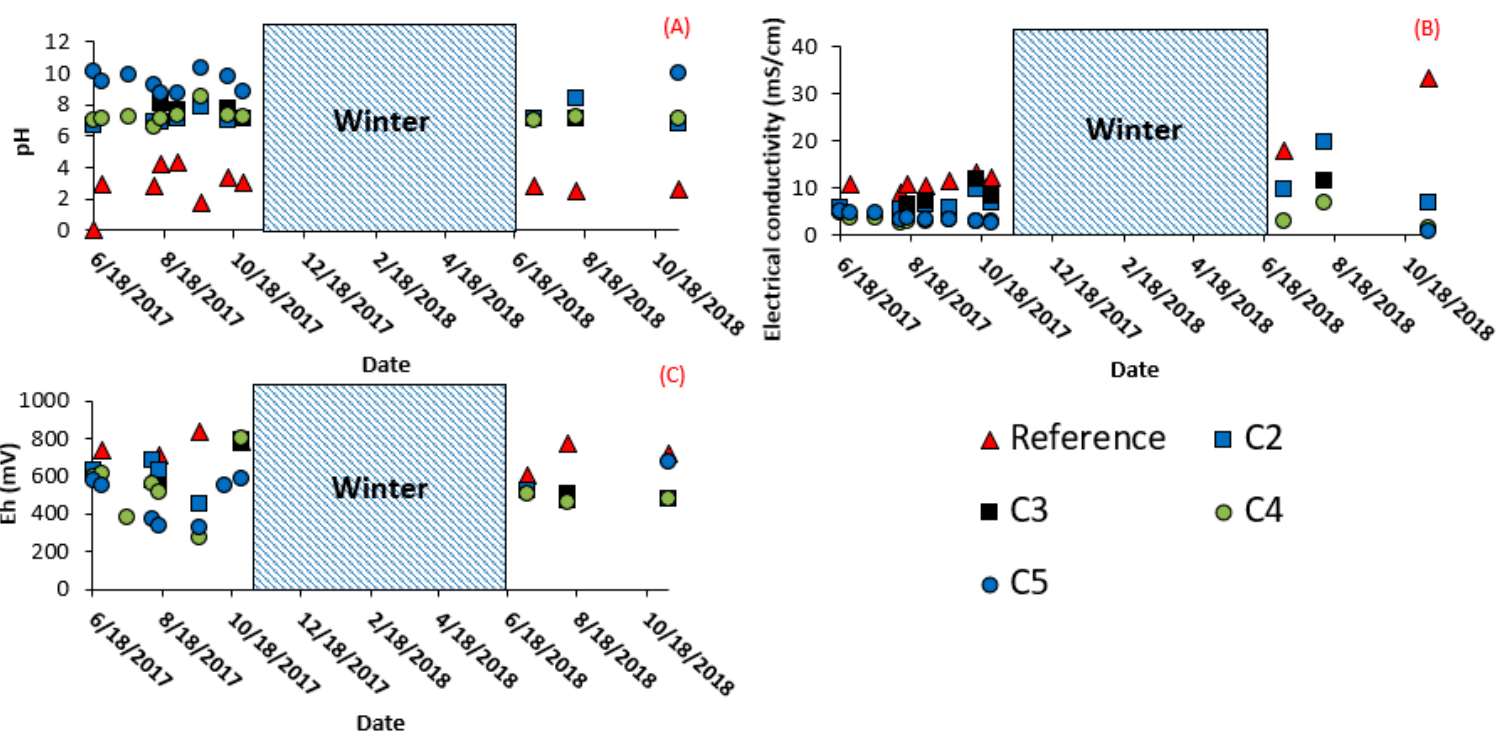

Figure 1. Evolution of (A) $\mathrm{pH},(\mathbf{B})$ electrical conductivity, and (C) Eh for leachates from vertical infiltration.

Vertical infiltration leachates from the five cells were analyzed for concentrations of $\mathrm{Ca}, \mathrm{Mg}, \mathrm{Mn}$, $\mathrm{Al}, \mathrm{Fe}, \mathrm{S}, \mathrm{Zn}, \mathrm{Cu}, \mathrm{As}$, and $\mathrm{Cr}$ to evaluate carbonate dissolution, sulfide oxidation, and metal(-oid) release rates (Figure 2). The end of the test was characterized by increased leaching of chemical species, including $\mathrm{Al}, \mathrm{S}, \mathrm{Cr}$, and $\mathrm{Zn}$. However, this could potentially be explained by the lower volumes of water collected at the end of the tests (October). Calcium concentrations differed slightly among the cells, with average concentrations of about $379 \mathrm{mg} / \mathrm{L}, 440 \mathrm{mg} / \mathrm{L}, 431 \mathrm{mg} / \mathrm{L}, 470 \mathrm{mg} / \mathrm{L}$, and $502 \mathrm{mg} / \mathrm{L}$ for $\mathrm{C} 1, \mathrm{C} 2, \mathrm{C} 3, \mathrm{C} 4$, and C5, respectively (Figure 2A). Average $\mathrm{Mg}$ concentrations were about $3756 \mathrm{mg} / \mathrm{L}$, $1790 \mathrm{mg} / \mathrm{L}, 2151 \mathrm{mg} / \mathrm{L}, 39 \mathrm{mg} / \mathrm{L}$, and $3.5 \mathrm{mg} / \mathrm{L}$ for C1, C2, C3, C4, and C5, respectively (Figure 2B). Average Mn concentrations were about $1421 \mathrm{mg} / \mathrm{L}, 45 \mathrm{mg} / \mathrm{L}, 44 \mathrm{mg} / \mathrm{L}, 1.5 \mathrm{mg} / \mathrm{L}$, and $0.7 \mathrm{mg} / \mathrm{L}$ for C1, C2, $\mathrm{C} 3, \mathrm{C} 4$, and C5, respectively (Figure 2C). The average Al concentration was about $16 \mathrm{mg} / \mathrm{L}$ for $\mathrm{C} 1$ and did not exceed $0.45 \mathrm{mg} / \mathrm{L}$ for the amended cells (Figure 2D). The same trend was observed for Fe, which had an average concentration of $1034 \mathrm{mg} / \mathrm{L}$ in $\mathrm{C} 1$ and $\leq 0.2 \mathrm{mg} / \mathrm{L}$ for the amended tailings (Figure 2E). Average $S$ concentrations were about $7523 \mathrm{mg} / \mathrm{L}, 2838 \mathrm{mg} / \mathrm{L}, 3289 \mathrm{mg} / \mathrm{L}, 707 \mathrm{mg} / \mathrm{L}$, and $890 \mathrm{mg} / \mathrm{L}$ for C1, C2, C3, C4, and C5, respectively (Figure 2F). Zinc concentrations were increased in leachates from $\mathrm{C} 1$, with an average concentration of about $17.6 \mathrm{mg} / \mathrm{L}$. Concentrations in the amended tailings did not exceed $1.4 \mathrm{mg} / \mathrm{L}$ (Figure 2G). Copper concentrations were higher for $\mathrm{C} 1$, with an average of $0.93 \mathrm{mg} / \mathrm{L}$, while concentrations in the amended tailings were negligible (Figure $2 \mathrm{H}$ ). Arsenic was only detected in leachates from C1, C2, and C3, with average concentrations of $0.28 \mathrm{mg} / \mathrm{L}, 0.29 \mathrm{mg} / \mathrm{L}$, and $0.20 \mathrm{mg} / \mathrm{L}$, respectively (Figure 2I). Finally, average Cr concentrations were about $0.42 \mathrm{mg} / \mathrm{L}$, $0.028 \mathrm{mg} / \mathrm{L}, 0.029 \mathrm{mg} / \mathrm{L}, 0.001 \mathrm{mg} / \mathrm{L}$, and 0.015 for C1, C2, C3, C4, and C5, respectively (Figure 2J). 

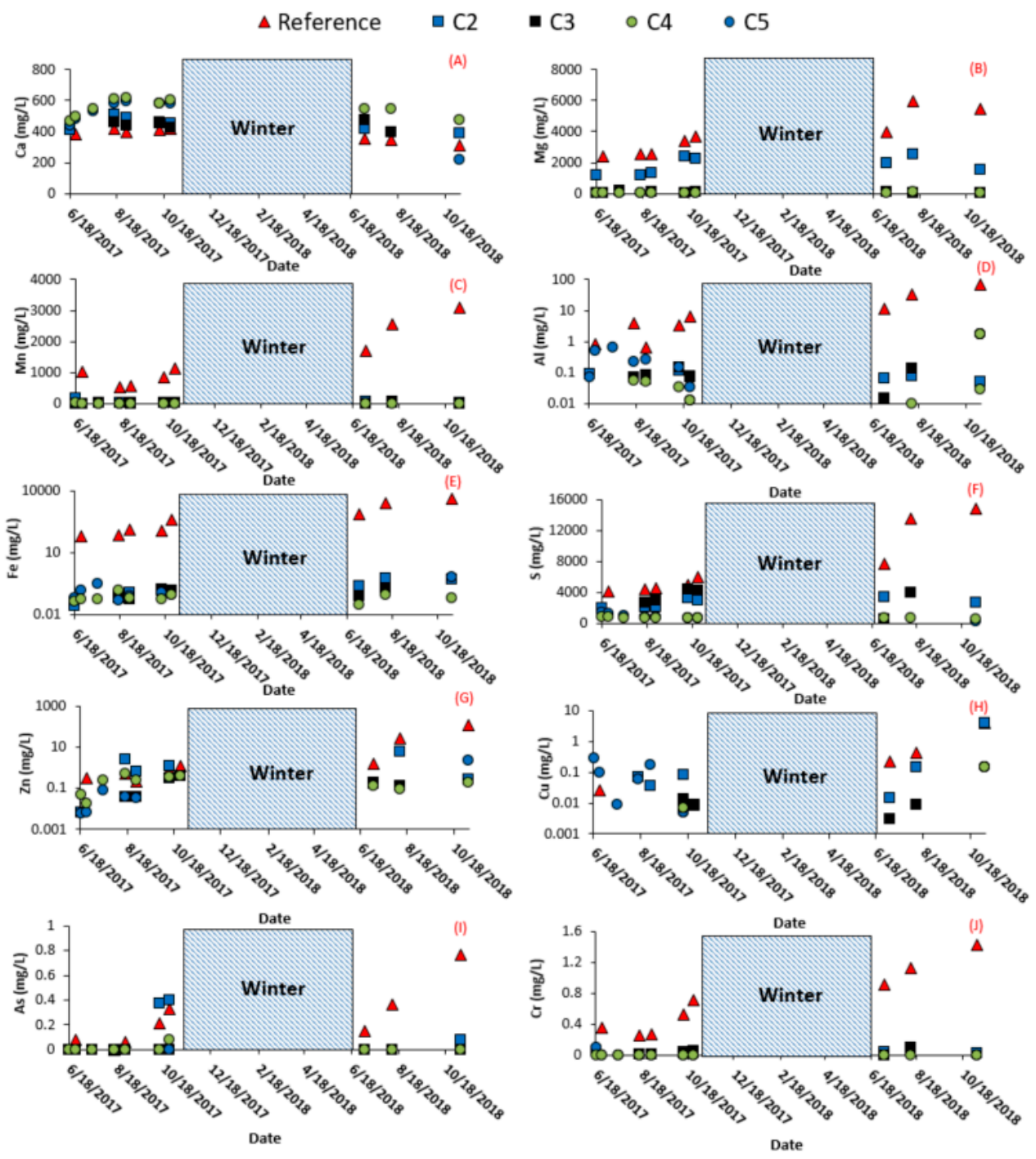

Figure 2. Evolution of concentrations of (A) Ca, (B) $\mathrm{Mg}$, (C) Mn, (D) $\mathrm{Al}$, (E) Fe, (F) S, (G) Zn, (H) Cu, (I) As, and (J) Cr in vertical infiltration waters.

\subsubsection{Surface and Subsurface Runoff}

Leachates collected from surface and subsurface runoff were analyzed for the same parameters as the leachates from vertical water infiltration. During the monitoring period, no leachates were collected from C4. Surface runoff from the control cell was acidic, with $\mathrm{pH}$ values less than 4 (Figure 3A), while the amended cells had $\mathrm{pH}$ values less than 6 . Thus, the different amendment formulations successfully neutralized the acidity produced by the oxidized tailings. Average EC values for all cells were below $3.6 \mathrm{mS} / \mathrm{cm}$ (Figure 3B) and Eh values were higher than $100 \mathrm{mV}$, suggesting oxidizing conditions (Figure 3C).

Leachates from surface and subsurface runoff showed a different chemical quality compared to leachates from vertical infiltration. In general, the runoff leachates showed lower concentrations for most cations. Average Ca concentrations were about $357 \mathrm{mg} / \mathrm{L}, 403 \mathrm{mg} / \mathrm{L}, 444 \mathrm{mg} / \mathrm{L}$, and $344 \mathrm{mg} / \mathrm{L}$ for C1, C2, C3, and C5, respectively (Figure 4A). Average Mg concentrations were about $66 \mathrm{mg} / \mathrm{L}, 153 \mathrm{mg} / \mathrm{L}$, $79 \mathrm{mg} / \mathrm{L}$, and $27 \mathrm{mg} / \mathrm{L}$ for C1, C2, C3, and C5, respectively (Figure 4B). Average Mn concentrations were about $27 \mathrm{mg} / \mathrm{L}$ for $\mathrm{C} 1$ and $<13 \mathrm{mg} / \mathrm{L}$ for the amended tailings (Figure $4 \mathrm{C}$ ). Average $\mathrm{Al}$ concentrations were $<0.8 \mathrm{mg} / \mathrm{L}$ for all cells (Figure 4D). Iron was leached in relatively high concentrations from C1, with an average concentration of about $37 \mathrm{mg} / \mathrm{L}$, but did not exceed $2 \mathrm{mg} / \mathrm{L}$ from the amended tailings 
(Figure 4E). Average $\mathrm{S}$ concentrations were about $500 \mathrm{mg} / \mathrm{L}$ for all cells (Figure $4 \mathrm{~F}$ ). $\mathrm{Zn}, \mathrm{Cu}$, As, and $\mathrm{Cr}$ were detected in low concentrations (Figure 4G-J).

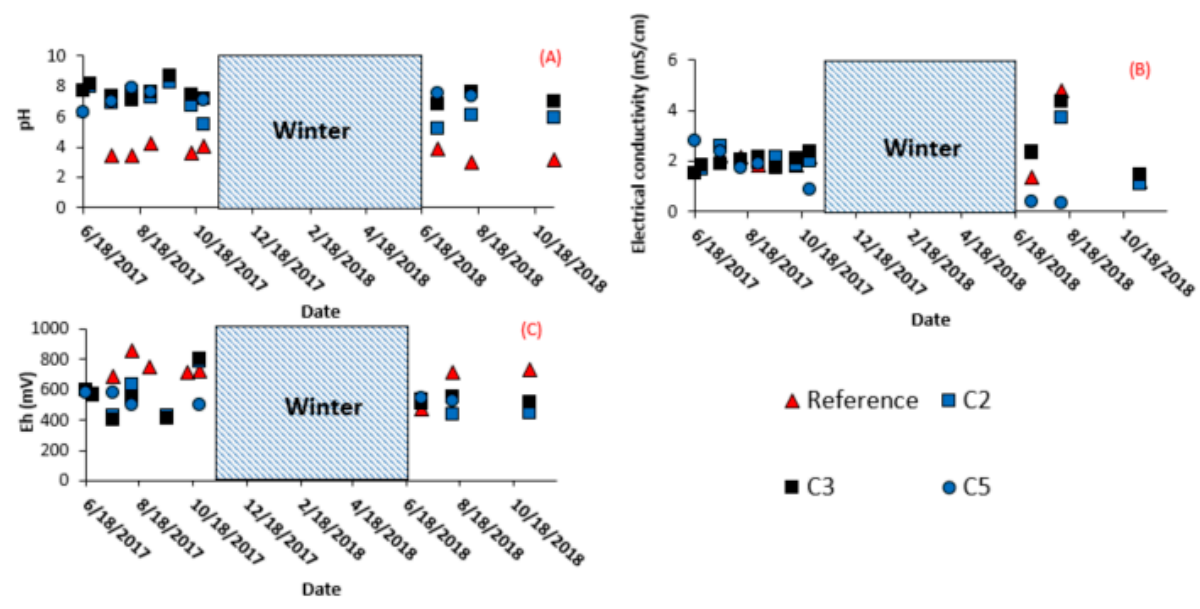

Figure 3. Evolution of (A) $\mathrm{pH},(\mathbf{B}) \mathrm{EC}$, and (C) Eh for leachates from surface runoff.

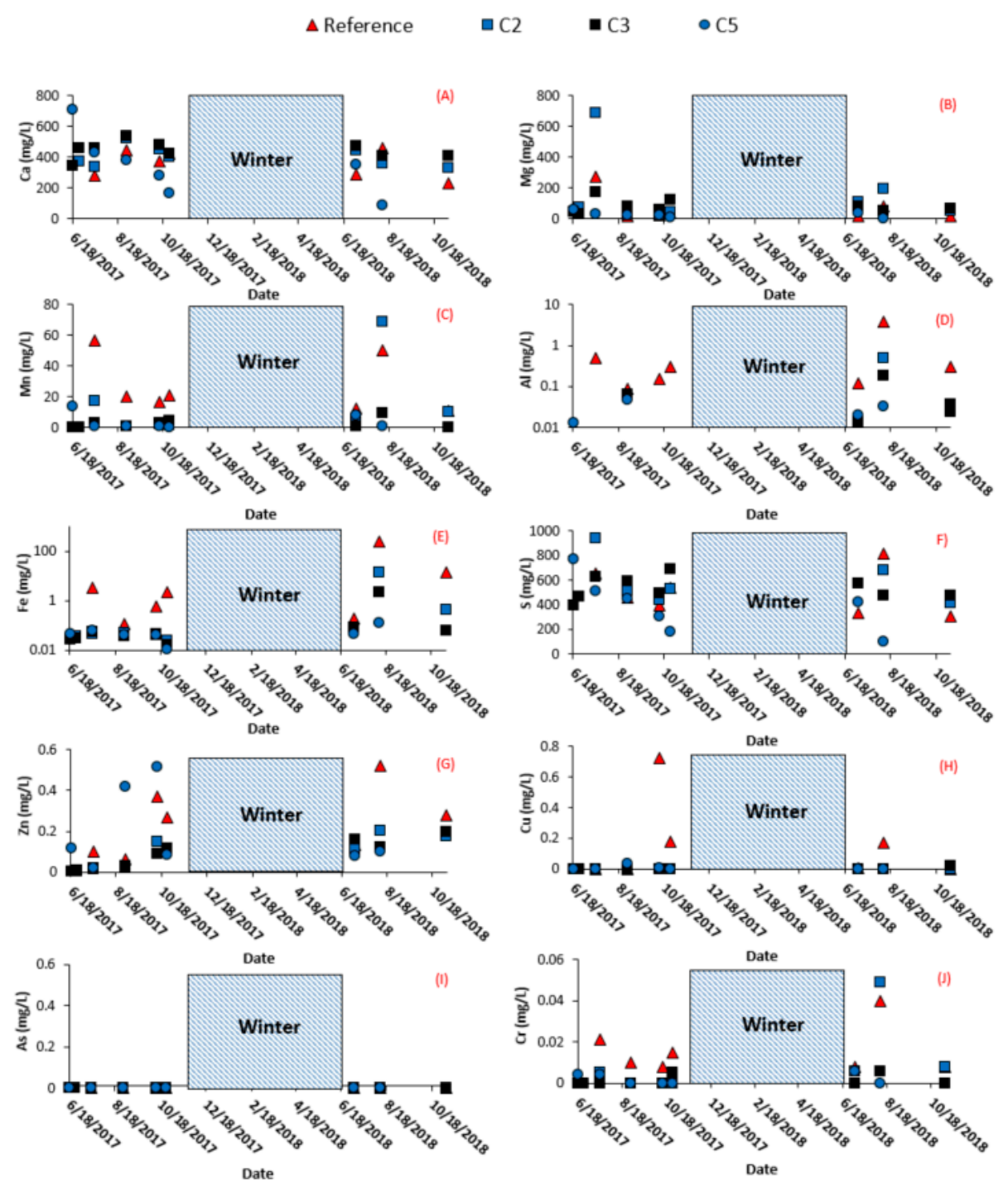

Figure 4. Evolution of concentrations of (A) Ca, (B) $\mathrm{Mg}$, (C) Mn, (D) $\mathrm{Al}$, (E) Fe, (F) S, (G) Zn, (H) Cu, (I) As, and (J) Cr for leachates from surface runoff. 


\subsection{Water Content Evolution}

The results of water content monitoring for the five cells are illustrated in Figure 5. Water contents showed the same seasonal variation for all five cells. Water contents decreased during winter and increased during summer. Cell C5 (with 5\% cement) showed the lowest VWC value at the end of the monitoring period. Cell C4 showed the highest VWC values over the two-year monitoring period. During the monitoring period, average VWCs were about $0.23,0.40,0.24,0.43$, and $0.26 \%$ for $\mathrm{C} 1, \mathrm{C} 2$, C3, C4, and C5, respectively. Additionally, the hydrogeological behavior of the cells observed in the field during sampling was very different. After a rain event, a water pool was observed within the cementitious cells. In addition, the volume of water collected in the barrel was always the smallest within $\mathrm{C} 5$ and $\mathrm{C} 4$, compared to that collected in the other cells.

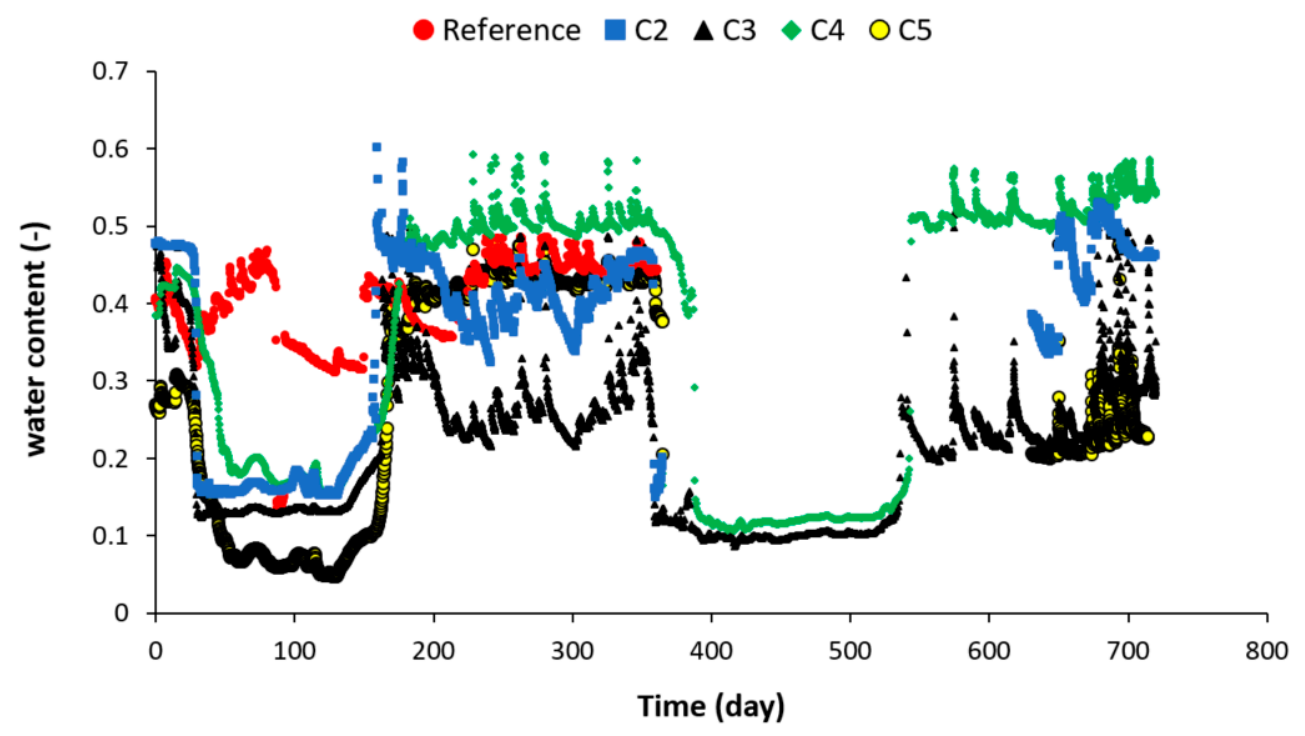

Figure 5. Evolution of volumetric water content (VWC) within the five field cells.

\subsection{Field Cell Dismantlement}

Samples taken from the field cells following the end of the monitoring period showed relatively similar mineralogical and chemical compositions (Table 3 and Figure 6A). The chemical compositions of the solid samples after the experiments were slightly variable among the cells. Al concentrations varied between 1.5 and $2.2 \mathrm{wt} \%$, Fe concentrations were between 20 and $29 \mathrm{wt} \%$, and S concentrations ranged between 4 and $7.5 \mathrm{wt} \%$ (other elements are presented in Table 3). The chemical differences among the samples are likely due to their different compositions (Table 1) and the initial differences due to the high volume of tailings used to fill the different cells.

Figure 6A shows a summary of the mineralogical compositions of the samples after two years of leaching tests. Sulfides consisted primarily of pyrite. Carbonates were mainly present as siderite, with moderate concentrations of calcite. Secondary minerals mainly included Fe oxides, gypsum, and $\mathrm{Fe}$ sulfates. The rest of the mineralogical composition comprised various silicates and other oxides.

Pyrite varied between 5 and $9 \mathrm{wt} \%$ and carbonate contents varied between 19 and $42 \mathrm{wt} \%$. Calcite was detected in high concentrations in samples from the $\mathrm{C} 3$, which initially contained $10 \%$ limestone. Iron oxides were detected in high concentrations in samples from $\mathrm{C} 1$. This could be explained by precipitation of secondary Fe phases, due to the high Fe concentrations within the reference cell, especially as compared to the other cells (Figure 2A). Iron oxides were present in the form of coatings on the surface of carbonates, sulfides, and silicates. Gypsum contents varied between 0.5 and $6 \mathrm{wt} \%$. 
The mineralogical composition of the studied samples shows Ca occurring primarily in gypsum in the sample from $\mathrm{C} 1$ and in carbonates in samples from the amended cells (Figure 6B). More than $70 \mathrm{wt} \%$ of Fe occurred in siderite and Fe oxides in all samples (Figure $6 \mathrm{C}$ ) and about $10 \mathrm{wt} \%$ of Fe occurred in pyrite. Sulfur was primarily associated with pyrite and gypsum (Figure 6D).

Sulfides and carbonates showed different degrees of liberation and associations (Figure 7). Mineral liberation analyses indicate the exposed areas of mineral. Pyrite was approximately 24, 13, 14, 28, and 18 wt \% liberated in samples from C1, C2, C3, C4, and C5, respectively (Figure 7A). Pyrite liberation analyses for $\mathrm{C} 4$ and $\mathrm{C} 5$ only took into account pyrite locking by mineral phases and not pyrite locking by the cementation of the tailings. Therefore, the pyrite liberation within cementitious amendment was overestimated in this case. The majority of the pyrite consisted of binary associations with $\mathrm{Ca}-\mathrm{Mg}$ carbonates and Fe oxides (Figure 8). Ca-Mg carbonates were about 0.62, 37, 51, 27, and $13 \mathrm{wt} \%$, liberated in samples from C1, C2, C3, C4, and C5, respectively (Figure 7B). The majority of $\mathrm{Ca}-\mathrm{Mg}$ carbonates consisted of binary associations with Fe oxides/siderite; they were about 24, 48, 44, 57 , and $68 \mathrm{wt} \%$ for samples from C1, C2, C3, C4, and C5, respectively. 
Table 3. Chemical composition of solid samples after field kinetic testing.

\begin{tabular}{cccccccccccccccccccccccccc}
\hline Elements (ppm) & $\mathbf{A l}$ & $\mathbf{A s}$ & $\mathbf{B a}$ & $\mathbf{B e}$ & $\mathbf{B i}$ & $\mathbf{C a}$ & $\mathbf{C d}$ & $\mathbf{C o}$ & $\mathbf{C r}$ & $\mathbf{C u}$ & $\mathbf{F e}$ & $\mathbf{K}$ & $\mathbf{L i}$ & $\mathbf{M g}$ & $\mathbf{M n}$ & $\mathbf{M o}$ & $\mathbf{N a}$ & $\mathbf{N i}$ & $\mathbf{P b}$ & $\mathbf{S}$ & $\mathbf{T i}$ & $\mathbf{Z n}$ \\
\hline Detection limit (ppm) & 60 & 5 & 5 & 5 & 5 & 60 & 5 & 5 & 5 & 10 & 10 & 1 & 5 & 15 & 5 & 5 & 1 & 5 & 5 & 200 & 25 & 55 \\
\hline C1 & 20,200 & 910 & 38 & $<5$ & 108 & 37,230 & 39 & $<5$ & 24 & $<10$ & 272,4002600 & $<5$ & 1515 & 4237 & 8 & 10,700 & 25 & 128 & 75,350 & 627 & 99 \\
C2 & 18,250 & 783 & 36 & $<5$ & 108 & 50,910 & 37 & $<5$ & 24 & $<10$ & 256,3002580 & $<5$ & 7839 & 6104 & 7 & 9360 & 27 & 102 & 71,600 & 317 & 96 \\
C3 & 15,360 & 654 & 31 & $<5$ & 109 & 106,000 & 30 & $<5$ & 22 & $<10$ & 221,0002530 & $<5$ & 10,940 & 5122 & 9 & 7810 & 23 & 99 & 66,060 & 486 & 85 \\
C3-duplicate & 15,150 & 673 & 32 & $<5$ & 105 & 100,900 & 30 & $<5$ & 22 & $<10$ & 208,9002520 & $<5$ & 11,100 & 5082 & 9 & 8090 & 24 & 98 & 64,600 & 501 & 83 \\
C4 & 21,930 & 399 & 66 & $<5$ & 104 & 33,660 & 37 & $<5$ & 36 & $<10$ & 291,2002210 & $<5$ & 9660 & 7698 & 6 & 12,900 & 21 & 105 & 57,920 & 865 & 115 \\
C5 & 21,970 & 426 & 49 & $<5$ & 100 & 40,720 & 38 & $<5$ & 40 & $<10$ & 281,8002110 & $<5$ & 7711 & 6775 & 8 & 12,600 & 21 & 136 & 43,100 & 756 & 107 \\
\hline
\end{tabular}



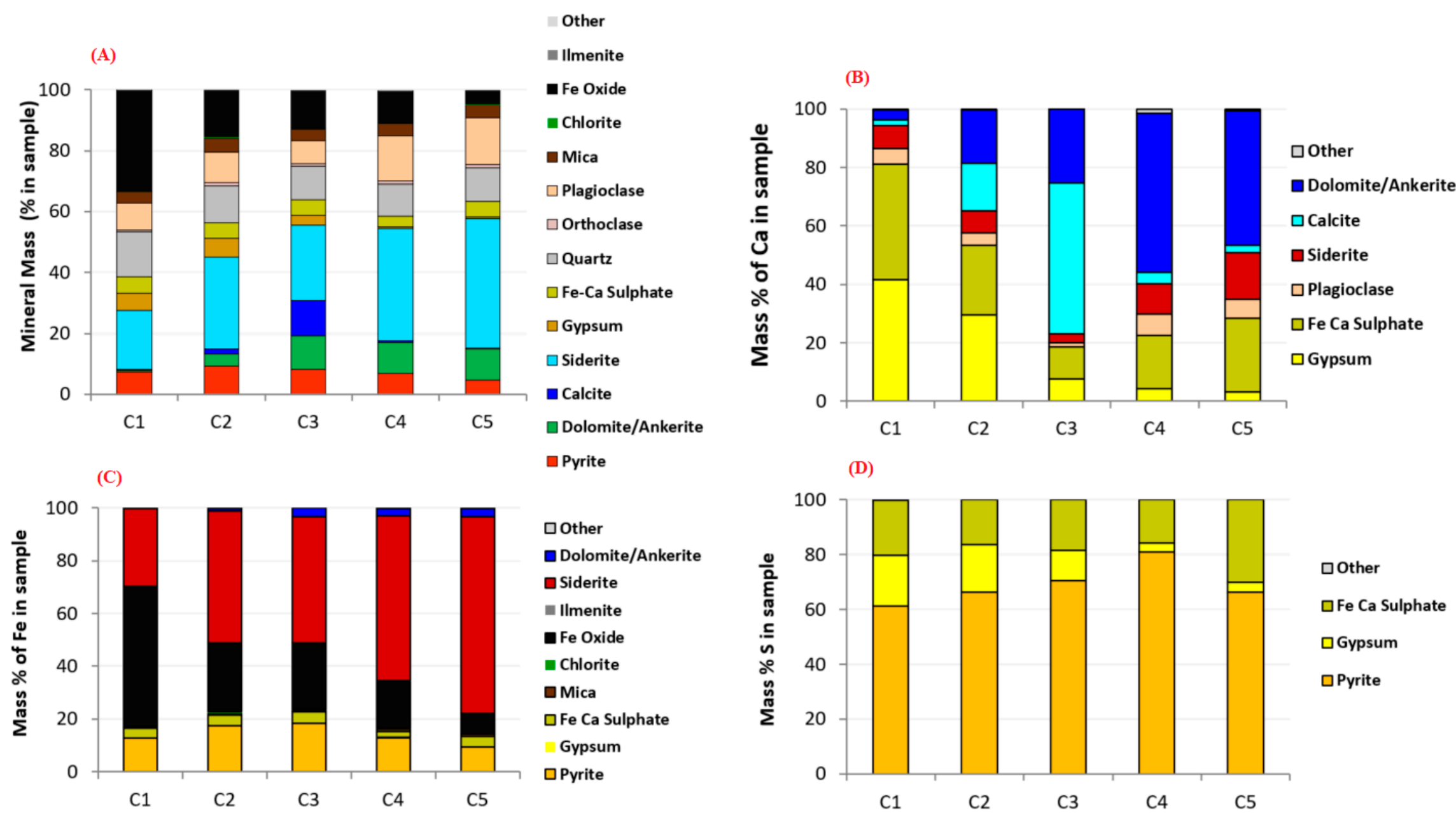

Figure 6. (A) Modal mineralogy for the dismantled samples; (B) Ca deportment; (C) Fe deportment; and (D) S deportment within the dismantled samples. 

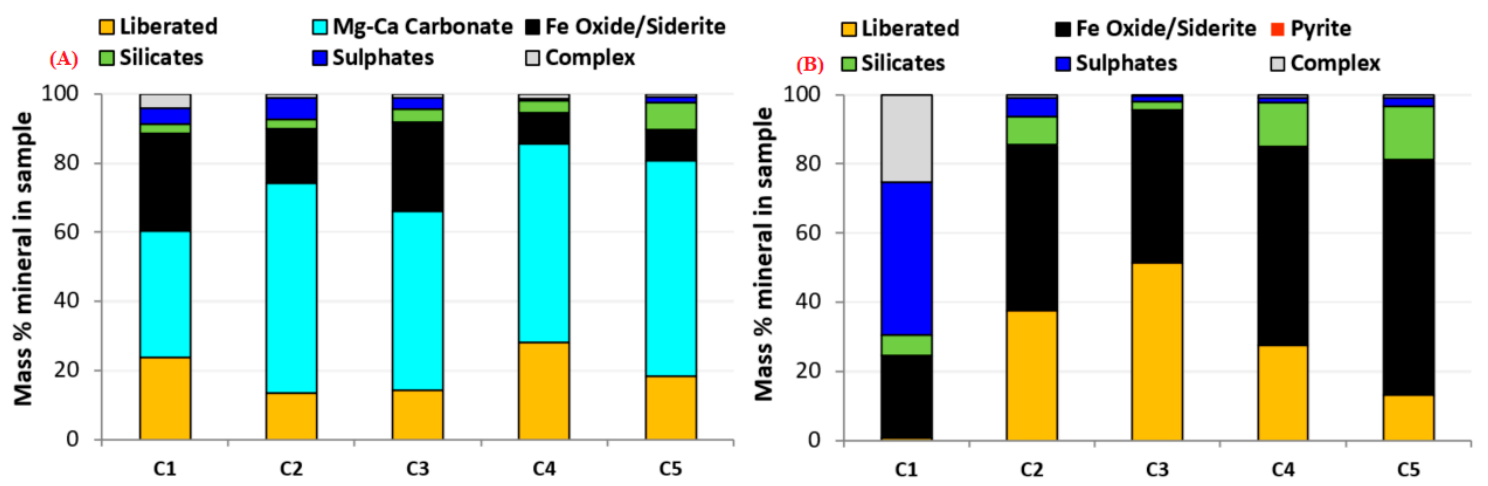

Figure 7. Degree of liberation for (A) carbonates and (B) sulfides.
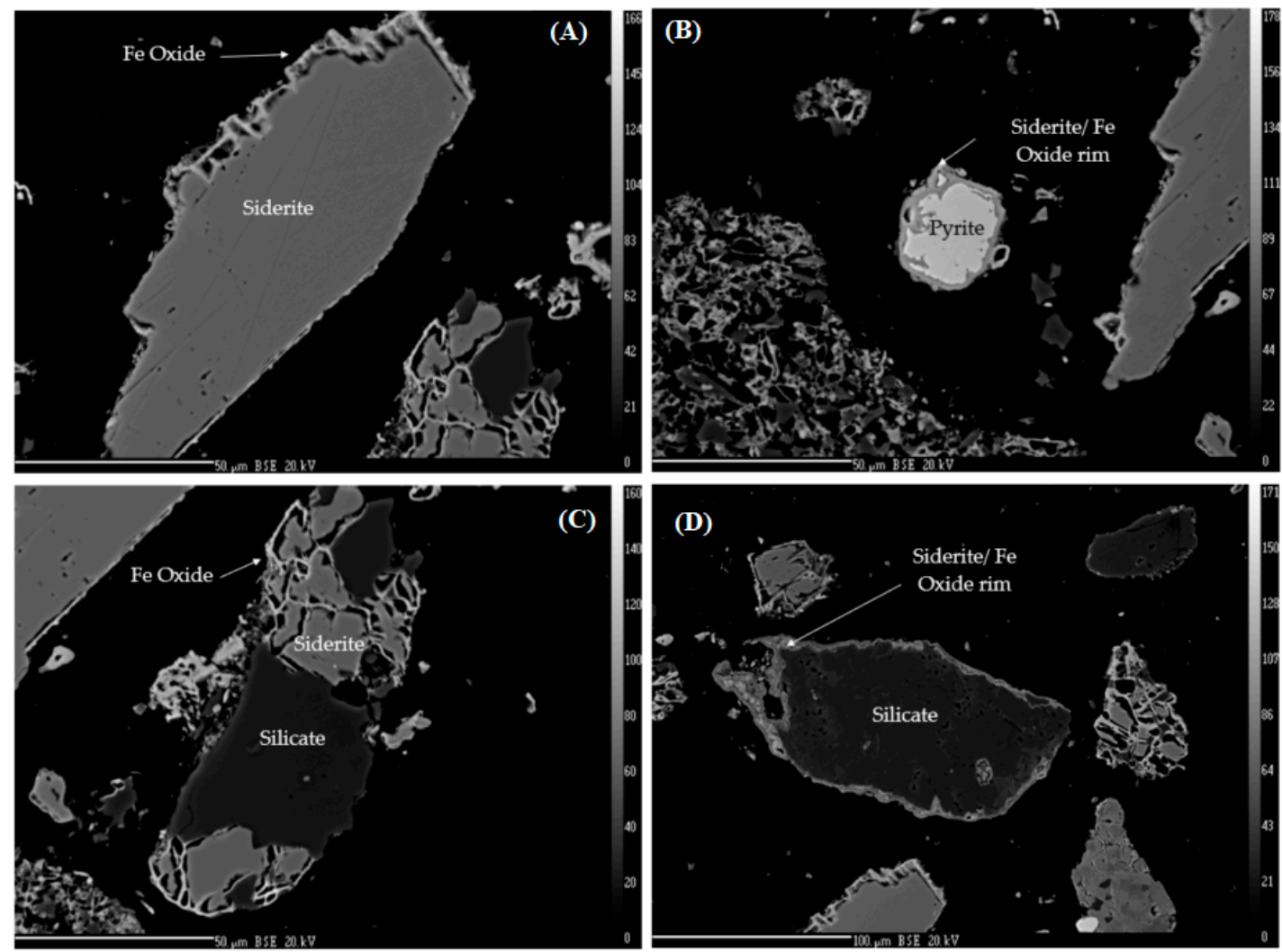

Figure 8. SEM images showing (A) siderite coated by Fe oxides, (B) pyrite coated by siderite and Fe oxides, and (C) and (D) silicates coated by Fe oxides and siderite.

\section{Discussion}

The oxidized tailings showed acidic $\mathrm{pH}$ values $(<4)$ and, together with other monitoring data, the $\mathrm{pH}$ measurements suggest that surface area and contact time considerably influence final water quality. Overall, leachates from vertical infiltration samples were more acidic and more loaded in chemical species than those from runoff samples. This makes sense as the contact time between water and tailings is greater during infiltration than during surface and subsurface runoff. Vertical water infiltration rates depend upon the physical and hydrogeological properties of the tailings [62-66]. However, surface runoff rates are greatly controlled by the morphological properties of the TSF (e.g., slope gradient, slope length) and the precipitation intensity [67-69].

The geochemical behavior of amended tailings showed that alkaline and cementitious amendments are both promising techniques that could be used for stabilizing and neutralizing acid-generating 
tailings. The leachates from the amended cells were characterized by circumneutral $\mathrm{pH}$ values and were less charged with chemical species than the control cell, except in the case of Ca, which was released more from cell C5 (5 wt \% OPC) (Summary of chemical analysis is presented in Table S1). In fact, the dissolution of carbonates and OPC produces alkalinity and buffers the $\mathrm{pH}$ of leachates $[11,15,31,38,57-59,70-79]$. The $\mathrm{pH}$ was established early, due to high dissolution rates of limestone and cement in the acidic media. The dissolution of carbonates (calcite) is explained by Equations (2) and (3):

$$
\begin{gathered}
\mathrm{CaCO}_{3(\mathrm{~s})}+2 \mathrm{H}_{(\mathrm{aq})}^{+} \rightarrow \mathrm{H}_{2} \mathrm{CO}_{3(\mathrm{aq})}+\mathrm{Ca}^{2+} \\
\mathrm{CaCO}_{3(\mathrm{~s})}+\mathrm{H}_{(\mathrm{aq})}^{+} \rightarrow \mathrm{HCO}_{3(\mathrm{aq})}^{-}+\mathrm{Ca}^{2+}
\end{gathered}
$$

Ca leaching was higher within $\mathrm{C}$, which contained OPC as a binder. In fact, the dissolution of tricalcium silicate (C3S), which is contained in OPC, is explained with the following reaction (Equation (4)):

$$
2 \mathrm{Ca}_{3} \mathrm{SiO}_{5}+6 \mathrm{H}_{2} \mathrm{O} \rightarrow 6 \mathrm{Ca}^{2+}+8 \mathrm{OH}^{-}+2 \mathrm{H}_{2} \mathrm{SiO}_{4}^{2-}
$$

Otherwise, Ca was released by gypsum and by carbonate dissolution in the control cell.

Other chemical species (As, Fe, Al, Li, $\mathrm{Pb}, \mathrm{Cr}, \mathrm{Li}$, and $\mathrm{Zn}$ ) were immobilized within the amended cells. The mechanisms responsible for the attenuation of these metal(-oid)s include: Precipitation, co-precipitation, and sorption related to the formation of secondary Fe oxyhydroxides at circumneutral $\mathrm{pH}$ values $[2,11,24]$. The Fe-S Eh-pH diagram illustrated in Figure 9 shows that Fe should precipitate as Fe oxides under the conditions observed in this study. However, for the cementitious amendments (C4 and C5), in addition to the precipitation of secondary Fe phases, two other mechanisms could be responsible for the attenuation of chemical species: (i) Physical trapping and (ii) reduction of water/tailings contact surface, due to hardening of the tailings by binders (FA and OPC). The application of cementitious additives enhances the mechanical resistance of tailings and increases their long-term impermeability $[20,44,60,61]$. As shown in Figure 10, all amendments used in this study were capable of decreasing the mobility of the analyzed metal(-oid)s, compared to the reference cell (with the exception of As and $\mathrm{Cr}$ in the vertical infiltration and runoff leachates from $\mathrm{C} 2$, respectively). A reduction factor was calculated for each analyte using Equation (5):

$$
R F=100 \times\left(1-\frac{C_{a}}{C_{0}}\right)
$$

where RF is the reduction factor, $C_{a}$ is the concentration of analyte in the amended cell, and $C_{0}$ is the concentration of the analyte in the reference cell.

The amendments reduced the $\mathrm{S}$ release from the $\mathrm{C} 2, \mathrm{C} 3, \mathrm{C} 4$, and $\mathrm{C} 5$ with respect to the control. However, more $\mathrm{S}$ was released from $\mathrm{C} 2$ and $\mathrm{C} 3$ than from $\mathrm{C} 4$ and $\mathrm{C} 5$. This could potentially be explained by the hardening of the tailings-cement mixture. Limestone amendments reduce the leaching of chemical species only by chemical process (e.g., precipitation of secondary phases); however, cementitious amendments reduce the leaching of chemical species by both chemical and physical processes (e.g., reducing the surface contact).

Iron was almost completely immobilized within the different amendment formulations, with RF values between 80 and $100 \%$. Aluminium concentrations were reduced by more than $90 \%$, with a maximum $\mathrm{RF}$ of $100 \%$ for $\mathrm{C} 3, \mathrm{C} 4$, and C5. Fe oxides precipitated in all cells, as illustrated in the mineralogical composition presented in Figure 6A. However, in $\mathrm{C} 1$, there were higher iron oxide concentrations. This could be explained by the $\mathrm{pH}-\mathrm{Eh}$ conditions. The $\mathrm{pH}$ in the reference cell was acidic, which means high reactivity of sulfides would be expected under these conditions. Zinc mobility was greatly reduced for infiltrating waters, however surface and subsurface runoff waters showed RF values between 23 and $67 \%$. Arsenic concentrations were completely reduced for the cementitious formulations with an RF of 100\%, except for the formulation C3 (10\% limestone) where it still released. Lead was successfully immobilized within RF values greater than $77 \%$ in all cases. The cells with 
cement showed the highest effectiveness regarding the As immobilization, due to: Hardening of tailings, which reduces the reactive surface, when the As is trapped within stable C-S-H phases [80]. The cementitious amendments offer more mechanisms to reduce the As leaching compared to alkaline amendments. Nickel showed RF values greater than $53 \%$. Finally, $\mathrm{Cr}$ was successfully stabilized by amendments $\mathrm{C} 3, \mathrm{C} 4$, and $\mathrm{C} 5$, while $\mathrm{C} 2$ showed appreciable concentrations in surface and subsurface runoff samples. The overall order of effectiveness of the different amendments was $\mathrm{C} 5=\mathrm{C} 4 \geq \mathrm{C} 3$ $\geq \mathrm{C} 2$. Therefore, the cementitious amendments appear to show a greater capacity to immobilize chemical species with respect to the tested alkaline amendments. The incorporation of fly ash to partially substitute the cement could reduce the costs related to the use of cementitious amendments. Considering both economic factors and overall effectiveness, the formulation with fly ash could be considered the best option. Furthermore, the cementitious amendments include the physical trapping of contaminants such as arsenic [44,47]. Indeed, the evolution of the VWC presented in Figure 5 shows that cell C5 had the lowest water content at the end of the test. This suggests that the infiltration speed is lower due to the hardening of the tailings.

Quantitative mineralogical analyses of the five cells showed that carbonates were more liberated compared to sulfides (Figure 7). Mineral liberation is recognized as a key factor in the reactivity of mine wastes [81-83]. After two years of monitoring, the reactive fraction of carbonates was higher than that of the sulfides.
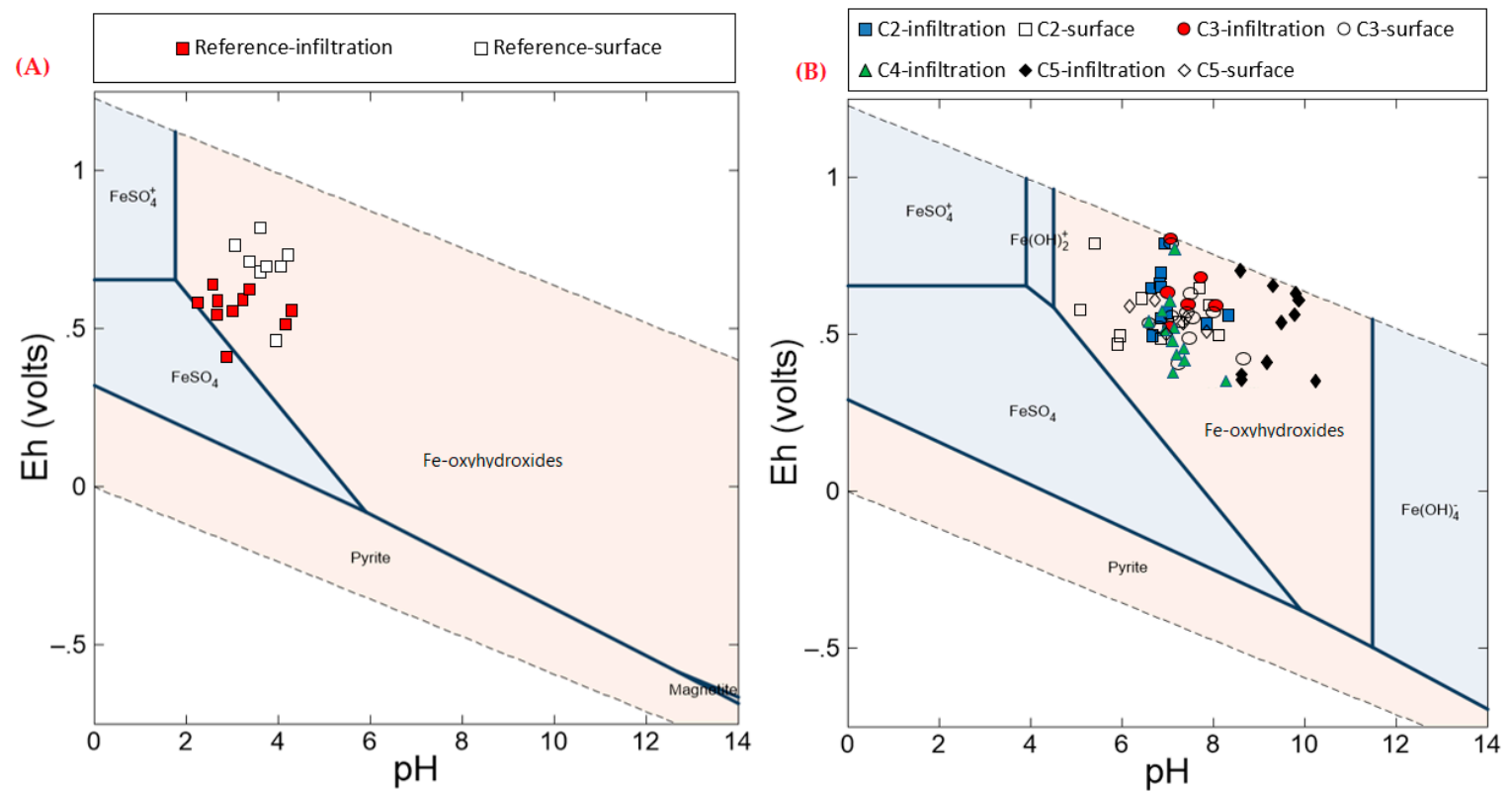

Figure 9. Fe and S pH-Eh diagrams for the leachates from (A) the reference cell and (B) amended tailings. 
(A)

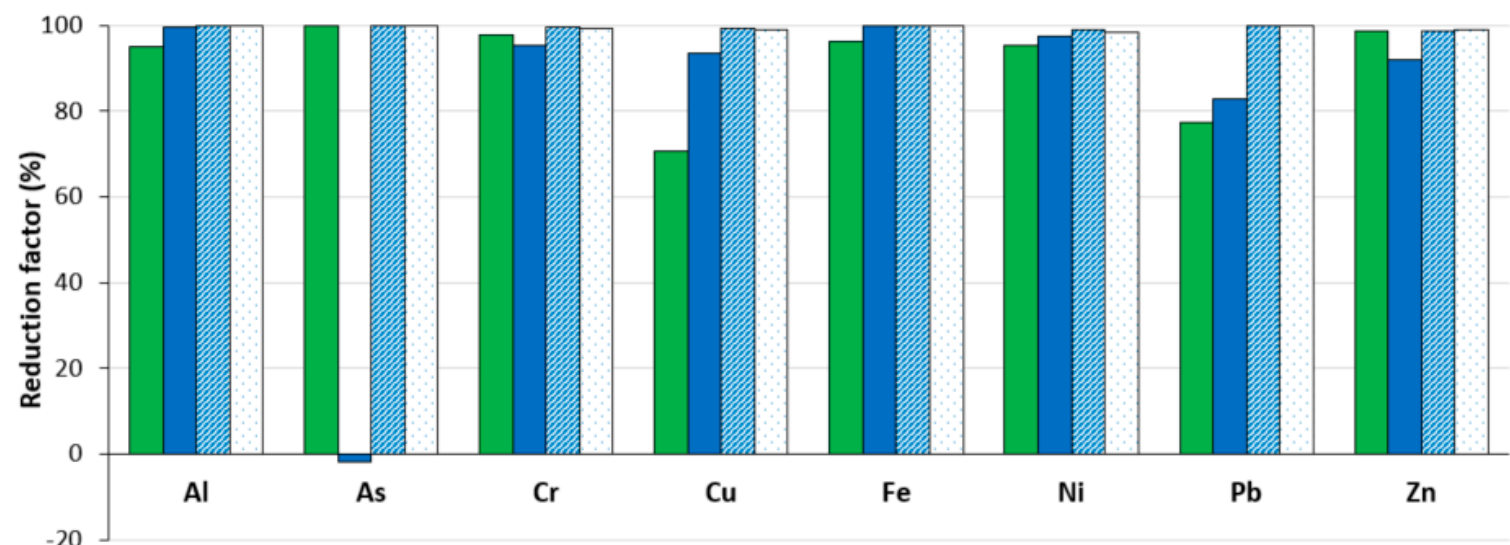

(B)

$\square$ C2-surface

口 C3-surface

$\square$ C5-surface

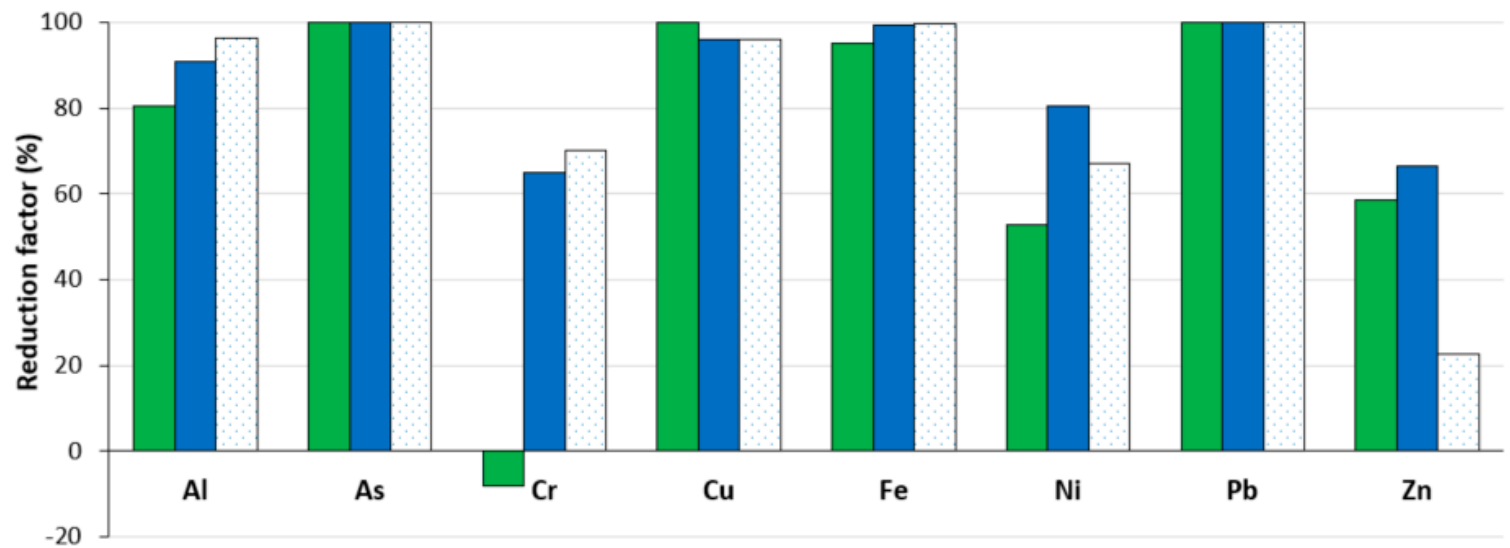

Figure 10. Reduction factors for $\mathrm{Al}, \mathrm{As}, \mathrm{Cr}, \mathrm{Cu}, \mathrm{Fe}, \mathrm{Ni}, \mathrm{Pb}$, and $\mathrm{Zn}$ for the different amendment formulations. (A) Vertical infiltration leachates; (B) surface and subsurface runoff leachates.

\section{Conclusions}

Reducing risks, such as acid generation and contaminant release from mine tailings, is a serious challenge facing the mining industry and requires the development of cost-effective techniques and technologies. The application of limestone as an alkaline amendment or ordinary Portland cement and fly ash as cementitious amendments showed promising results to neutralize the acid produced and contaminants released from oxidized tailings, based on short-term, in situ tests. Furthermore, OPC was successfully partially substituted with fly ash, which could reduce the costs associated with cementitious amendments. In this study, cementitious amendments showed a high effectiveness compared to alkaline amendments. In fact, metal and metalloid concentrations were reduced more by both tested cementitious amendments than by the tested limestone amendments, which failed to attenuate $\mathrm{Zn}$ and As releases when applied at $5 \%$ and $10 \%$, respectively. However, the applicability of mining amendments as a reclamation technique must consider two major points: i) The long-term behavior of amended tailings and for how long the contaminants will be immobilized, and ii) the cost related to applying the amendment. Economic factors will be greatly affected by the availability of the amendment materials at a close proximity to the mine site.

Supplementary Materials: The following are available online at http://www.mdpi.com/2075-163X/9/5/314/s1, Figure S1: Images showing field cells construction and amendments mixing with oxidized tailing, Figure S2: Schematic representation of the cells constructed in the TSF (image not to scale), Figure S3: Calibration curves of the volumetric water content probes, Figure S4: Average daily temperature, Table S1: Summary of chemical 
concentrations of the leachates from the different cells $(\leq \mathrm{LD}$ means that the concentration was inferior to the detection limit of ICP-AES).

Author Contributions: Conceptualization, A.E., M.B., B.B., and T.G.; formal analysis and investigation, A.E. and T.G.; writing—original draft preparation, A.E. and M.B.; writing—review and editing, A.E., M.B., B.B., and T.G.; project administration, M.B. and B.B.

Funding: Funding for this study was provided by Mitacs (https://www.mitacs.ca/fr, project number IT10661) and the NSERC-UQAT Industrial Research Chair on Mine Site Reclamation and its partners.

Acknowledgments: The authors thank Mitacs (https://www.mitacs.ca/fr), Agnico-Eagle, and the NSERC UQAT Industrial Research Chair on Mine Site Reclamation and its partners for supporting this study. The authors thank URSTM staff for their support in the laboratory and the field and Gary Schudel for comments on the manuscript.

Conflicts of Interest: The authors declare no conflict of interest.

\section{References}

1. Rodriguez, L.; Gómez, R.; Sánchez, V.; Villaseñor, J.; Alonso-Azcárate, J. Performance of waste-based amendments to reduce metal release from mine tailings: One-year leaching behaviour. J. Environ. Manag. 2018, 209, 1-8. [CrossRef] [PubMed]

2. Yi, Y.; Wen, J.; Zeng, G.; Zhang, T.; Huang, F.; Qin, H.; Tian, S. A comparative study for the stabilisation of heavy metal contaminated sediment by limestone, $\mathrm{MnO}_{2}$ and natural zeolite. Environ. Sci. Pollut. Res. 2017, 24, 795-804. [CrossRef]

3. Chen, Q.; Tyrer, M.; Hills, C.; Yang, X.; Carey, P. Immobilisation of heavy metal in cement-based solidification/stabilisation: A review. Waste Manag. 2009, 29, 390-403. [CrossRef]

4. Wang, F.; Shen, Z.; Al-Tabbaa, A. PC-based and MgO-based binders stabilised/solidified heavy metal-contaminated model soil: Strength and heavy metal speciation in early stage. Géotechnique 2018, 68, 1025-1030. [CrossRef]

5. Falciglia, P.P.; Romano, S.; Vagliasindi, F.G. Stabilisation/Solidification of soils contaminated by mining activities: Influence of barite powder and grout content on $\gamma$-radiation shielding, unconfined compressive strength and 232Th immobilisation. J. Geochem. Explor. 2017, 174, 140-147. [CrossRef]

6. Mitchell, K.; Trakal, L.; Sillerova, H.; Avelar-González, F.J.; Guerrero-Barrera, A.L.; Hough, R.; Beesley, L. Mobility of As, $\mathrm{Cr}$ and $\mathrm{Cu}$ in a contaminated grassland soil in response to diverse organic amendments; a sequential column leaching experiment. Appl. Geochem. 2018, 88, 95-102. [CrossRef]

7. Wang, F.; Wang, H.; Jin, F.; Al-Tabbaa, A. The performance of blended conventional and novel binders in the in-situ stabilisation/solidification of a contaminated site soil. J. Hazard. Mater. 2015, 285, 46-52. [CrossRef] [PubMed]

8. AlKattan, M.; Oelkers, E.H.; Dandurand, J.-L.; Schott, J. An experimental study of calcite and limestone dissolution rates as a function of $\mathrm{pH}$ from -1 to 3 and temperature from 25 to $80^{\circ} \mathrm{C}$. Chem. Geol. 1998, 151, 199-214. [CrossRef]

9. Fatahi, B.; Khabbaz, H. Influence of Chemical Stabilisation on Permeability of Municipal Solid Wastes. Geotech. Geol. Eng. 2015, 33, 455-466. [CrossRef]

10. Pesonen, J.; Yliniemi, J.; Illikainen, M.; Kuokkanen, T.; Lassi, U. Stabilization/solidification of fly ash from fluidized bed combustion of recovered fuel and biofuel using alkali activation and cement addition. J. Environ. Chem. Eng. 2016, 4, 1759-1768. [CrossRef]

11. Doye, I.; Duchesne, J. Neutralisation of acid mine drainage with alkaline industrial residues: Laboratory investigation using batch-leaching tests. Appl. Geochem. 2003, 18, 1197-1213. [CrossRef]

12. Paradis, M.; Duchesne, J.; Lamontagne, A.; Isabel, D. Using red mud bauxite for the neutralization of acid mine tailings: A column leaching test. Can. Geotech. J. 2006, 43, 1167-1179. [CrossRef]

13. Ahmaruzzaman, M. A review on the utilization of fly ash. Prog. Energy Combust. Sci. 2010, 36, 327-363. [CrossRef]

14. Fleri, M.A.; Whetstone, G.T. In situ stabilisation/solidification: Project lifecycle. J. Hazard. Mater. 2007, 141, 441-456. [CrossRef]

15. Cravotta III, C.A.; Trahan, M.K. Limestone drains to increase $\mathrm{pH}$ and remove dissolved metals from acidic mine drainage. Appl. Geochem. 1999, 14, 581-606. [CrossRef] 
16. de Andrade, R.P.; Figueiredo, B.R.; de Mello, J.W.V.; Santos, J.C.Z.; Zandonadi, L.U.; Andrade, R.P.; Mello, J.W.V. Control of geochemical mobility of arsenic by liming in materials subjected to acid mine drainage. J. Soils Sediments 2008, 8, 123-129. [CrossRef]

17. Hakkou, R.; Benzaazoua, M.; Bussière, B. Laboratory Evaluation of the Use of Alkaline Phosphate Wastes for the Control of Acidic Mine Drainage. Mine Water Environ. 2009, 28, 206-218. [CrossRef]

18. Du, Y.J.; Jiang, N.J.; Liu, S.Y.; Jin, F.; Singh, D.N.; Puppala, A.J. Engineering properties and microstructural characteristics of cement-stabilized zinc-contaminated kaolin. Can. Geotech. J. 2013, 51, 289-302. [CrossRef]

19. Li, X.D.; Poon, C.S.; Sun, H.; Lo, I.M.; Kirk, D.W. Heavy metal speciation and leaching behaviors in cement based solidified/stabilized waste materials. J. Hazard. Mater. 2001, 82, 215-230. [CrossRef]

20. Nehdi, M.; Tariq, A. Stabilization of sulphidic mine tailings for prevention of metal release and acid drainage using cementitious materials: A review. J. Environ. Eng. Sci. 2007, 6, 423-436. [CrossRef]

21. Kogbara, R.B.; Yi, Y.; Al-Tabbaa, A. Process envelopes for stabilisation/solidification of contaminated soil using lime-slag blend. Environ. Sci. Pollut. Res. 2011, 18, 1286-1296. [CrossRef]

22. Yilmaz, E.; Benzaazoua, M.; Bussière, B.; Pouliot, S. Influence of disposal configurations on hydrogeological behaviour of sulphidic paste tailings: A field experimental study. Int. J. Process. 2014, 131, 12-25. [CrossRef]

23. Gilles, B.; Benzaazoua, M.; Maqsoud, A.; Bussière, B. Long term hydro-geochemical behaviour of surface paste disposal in field experimental cells. In Proceedings of the Conference Canadienne de Ge'otechnique, GeoRegina, CD-Rom, Regina, Slovakia, 28 September-2 October 2014; Volume 1, p. 19.

24. Komnitsas, K.; Bartzas, G.; Paspaliaris, I. Efficiency of limestone and red mud barriers: Laboratory column studies. Miner. Eng. 2004, 17, 183-194. [CrossRef]

25. Mylona, E.; Xenidis, A.; Paspaliaris, I. Inhibition of acid generation from sulphidic wastes by the addition of small amounts of limestone. Miner. Eng. 2000, 13, 1161-1175. [CrossRef]

26. Holmstrom, H.; Ljungberg, J.; Ohlander, B. Role of carbonates in mitigation of metal release from mining waste. Evidence from humidity cells tests. Environ. Geol. 1999, 37, 267-280. [CrossRef]

27. Duchesne, J.; Reardon, E. Determining controls on element concentrations in cement kiln dust leachate. Waste Manag. 1998, 18, 339-350. [CrossRef]

28. Acero, P.; Ayora, C.; Torrentó, C.; Nieto, J.-M. The behavior of trace elements during schwertmannite precipitation and subsequent transformation into goethite and jarosite. Geochim. Cosmochim. Acta 2006, 70, 4130-4139. [CrossRef]

29. Asta, M.P.; Ayora, C.; Román-Ross, G.; Cama, J.; Acero, P.; Gault, A.G.; Charnock, J.M.; Bardelli, F. Natural attenuation of arsenic in the Tinto Santa Rosa acid stream (Iberian Pyritic Belt, SW Spain): The role of iron precipitates. Chem. Geol. 2010, 271, 1-12. [CrossRef]

30. Benjamin, M.M.; O Leckie, J. Competitive adsorption of $\mathrm{cd}, \mathrm{cu}, \mathrm{zn}$, and $\mathrm{pb}$ on amorphous iron oxyhydroxide. J. Colloid Interface Sci. 1981, 83, 410-419. [CrossRef]

31. Blowes, D.W.; Ptacek, C.J.; Jambor, J.L.; Weisener, C.G. The geochemistry of acid mine drainage. In Treatise on Geochemistry; Elsevier: Amsterdam, The Netherlands, 2014.

32. Belzile, N.; Maki, S.; Chen, Y.-W.; Goldsack, D. Inhibition of pyrite oxidation by surface treatment. Sci. Total Environ. 1997, 196, 177-186. [CrossRef]

33. Cai, M.-F.; Dang, Z.; Chen, Y.-W.; Belzile, N. The passivation of pyrrhotite by surface coating. Chemosphere 2005, 61, 659-667. [CrossRef] [PubMed]

34. Harrison, A.L.; Dipple, G.M.; Power, I.M.; Mayer, K.U. Influence of surface passivation and water content on mineral reactions in unsaturated porous media: Implications for brucite carbonation and $\mathrm{CO}_{2}$ sequestration. Geochim. Cosmochim. Acta 2015, 148, 477-495. [CrossRef]

35. Kang, C.U.; Jeon, B.H.; Park, S.S.; Kang, J.S.; Kim, K.H.; Kim, D.K.; Choi, U.-K.; Kim, S.J. Inhibition of pyrite oxidation by surface coating: A long-term field study. Environ. Geochem. Health 2016, 38, 1137-1146. [CrossRef] [PubMed]

36. Evangelou, V.P.; Zhang, Y.L. A review: Pyrite oxidation mechanisms and acid mine drainage prevention. Crit. Rev. Environ. Sci. Technol. 1995, 25, 141-199. [CrossRef]

37. Nedem. Diversité Microbiologique Dans La Production De Drainage Minier Acide À La halde Sud De La Mine Doyon. Mend/Medem 1997.

38. Nordstrom, D.K.; Southam, G. Geomicrobiology of sulfide mineral oxidation. Rev. Mineral. 1997, 35, 361-390. 
39. Lamontagne, A. Étude De La Méthode D'empilement Des Stériles Par Entremêlement Par Couches Pour Contrôler Le Drainage Minier Acide. Ph.D. Thesis, Université Laval, Quebec City, QC, Cannada, 2001.

40. Mackie, A.L.; Walsh, M.E. Investigation into the use of cement kiln dust in high density sludge (HDS) treatment of acid mine water. Water Res. 2015, 85, 443-450. [CrossRef] [PubMed]

41. Duchesne, J.; Laforest, G. Remediation of electric arc furnace dust leachate by the use of cementitious materials: A column-leaching test. Chin. J. Geochem. 2006, 25, 99. [CrossRef]

42. Ichrak, H.; Mostafa, B.; Abdelkabir, M.; Bruno, B. Effect of cementitious amendment on the hydrogeological behavior of a surface paste tailings' disposal. Innov. Infrastruct. Solut. 2016, 1, 19. [CrossRef]

43. Tariq, A.; Yanful, E.K. A review of binders used in cemented paste tailings for underground and surface disposal practices. J. Environ. Manag. 2013, 131, 138-149. [CrossRef]

44. Benzaazoua, M.; Marion, P.; Picquet, I.; Bussière, B. The use of pastefill as a solidification and stabilization process for the control of acid mine drainage. Miner. Eng. 2004, 17, 233-243. [CrossRef]

45. Deschamps, T.; Benzaazoua, M.; Bussière, B.; Aubertin, M. Les effets d'amendements alcalins sur des résidus miniers sulfureux entreposés en surface: Cas des dépôts en pâte. Déchets Sci. Tech. 2009, 19. [CrossRef]

46. Ciccu, R.; Ghiani, M.; Serci, A.; Fadda, S.; Peretti, R.; Zucca, A. Heavy metal immobilization in the mining-contaminated soils using various industrial wastes. Miner. Eng. 2003, 16, 187-192. [CrossRef]

47. Coussy, S.; Benzaazoua, M.; Blanc, D.; Moszkowicz, P.; Bussière, B. Arsenic stability in arsenopyrite-rich cemented paste backfills: A leaching test-based assessment. J. Hazard. Mater. 2011, 185, 1467-1476. [CrossRef]

48. Criado, M.; Fernández-Jiménez, A.; Palomo, A. Alkali activation of fly ash: Effect of the SiO2/Na2O ratio. Microporous Mesoporous Mater. 2007, 106, 180-191. [CrossRef]

49. Kim, J.W.; Jung, M.C. Solidification of arsenic and heavy metal containing tailings using cement and blast furnace slag. Environ. Geochem. Health 2011, 33 (Suppl. 1), 151-158. [CrossRef]

50. Kumpiene, J.; Lagerkvist, A.; Maurice, C. Stabilization of As, Cr, Cu, Pb and $\mathrm{Zn}$ in soil using amendments-A review. Waste Manag. 2008, 28, 215-225. [CrossRef]

51. Park, C.-K. Hydration and solidification of hazardous wastes containing heavy metals using modified cementitious materials. Cem. Concr. Res. 2000, 30, 429-435. [CrossRef]

52. Peyronnard, O; Benzaazoua, M. Alternative by-product based binders for cemented mine backfill: Recipes optimisation using Taguchi method. Miner. Eng. 2012, 29, 28-38. [CrossRef]

53. Elghali, A.; Benzaazoua, M.; Bussière, B.; Kennedy, C.; Parwani, R.; Graham, S. The role of hardpan formation on the reactivity of sulfidic mine tailings: A case study at Joutel mine (Québec). Sci. Total Environ. 2019, 654, 118-128. [CrossRef]

54. Elghali, A.; Benzaazoua, M.; Bussière, B.; Genty, T. Spatial Mapping of Acidity and Geochemical Properties of Oxidized Tailings within the Former Eagle/Telbel Mine Site. Minerals 2019, 9, 180. [CrossRef]

55. Bussière, B.; Mbonimpa, M.; Molson, J.W.; Chapuis, R.P.; Aubertin, M. Field experimental cells to evaluate the hydrogeological behaviour of oxygen barriers made of silty materials. Can. Geotech. J. 2007, 44, 245-265. [CrossRef]

56. Bouzahzah, H.; Benzaazoua, M.B.; Bussiere, P.B. A quantitative approach for the estimation of the "fizz rating" parameter in the acid-base accounting tests: A new adaptations of the Sobek test. J. Geochem. Explor. 2015, 153, 53-65. [CrossRef]

57. Blowes, D.W.; Ptacek, C.J.; Jambor, J.L.; Weisener, C.G. The geochemistry of acid mine drainage. Treatise Geochem. 2003, 9, 612.

58. Blowes, D.W.; Jambor, J.L.; Alpers, C.N. The Environmental Geochemistry of Sulfide Mine-Wastes; Mineralogical Association of Canada: Québec, QC, Canada, 1994; Volume 22.

59. Blowes, D.W.; Ptacek, C.J.; Jambor, J. Mineralogy of mine wastes and strategies for remediation. In Environmental Mineralogy; Vaughan, D.J., Wogelius, R.A., Eds.; European Mineralogical Union: Jena, Germany, 2013; Volume 13, pp. 295-338.

60. Benzaazoua, M.; Belem, T.; Bussière, B. Chemical factors that influence the performance of mine sulphidic paste backfill. Cem. Concr. Res. 2002, 32, 1133-1144. [CrossRef]

61. Benzaazoua, M.; Ouellet, J.; Servant, S.; Newman, P.; Verburg, R. Cementitious backfill with high sulfur content Physical, chemical, and mineralogical characterization. Cem. Concr. Res. 1999, 29, 719-725. [CrossRef]

62. Beven, K.; Germann, P. Macropores and water flow in soils. Water Resour. Res. 1982, 18, 1311-1325. [CrossRef] 
63. Bussière, B.; Aubertin, M.; Julien, M. Couvertures avec effets de barrière capillaire pour limiter le drainage minier acide: Aspects théoriques et pratiques. Vecteur Environ. 2001, 34, 37-50.

64. Childs, E.C.; Bybordi, M. The vertical movement water in stratified porous material: 1. Infiltration. Water Resour. Res. 1969, 5, 446-459. [CrossRef]

65. Bear, J. Hydraulics of Groundwater; Courier Corporation: Chelmsford, MA, USA, 2012.

66. Whitaker, S. Flow in porous media I: A theoretical derivation of Darcy's law. Transp. Porous Media 1986, 1, 3-25. [CrossRef]

67. Getter, K.L.; Rowe, D.B.; Andresen, J.A. Quantifying the effect of slope on extensive green roof stormwater retention. Ecol. Eng. 2007, 31, 225-231. [CrossRef]

68. Dunne, T.; Zhang, W. Effects of Rainfall, Vegetation, and Microtopography on Infiltration and Runoff. Water Resour. Res. 1991, 27, 2271-2285. [CrossRef]

69. Vermang, J.; Norton, L.; Huang, C.; Cornelis, W.; Da Silva, A.; Gabriels, D. Characterization of Soil Surface Roughness Effects on Runoff and Soil Erosion Rates under Simulated Rainfall. Soil Sci. Soc. J. 2015, 79, 903-916. [CrossRef]

70. Jambor, J. Mineralogy of sulfide-rich tailings and their oxidation products. Environ. Geochem. Sulfide Mine Wastes 1994, 22, 59-102.

71. Jambor, J.; Dutrizac, J.; Groat, L.; Raudsepp, M. Static tests of neutralization potentials of silicate and aluminosilicate minerals. Environ. Geol. 2002, 43, 1-17.

72. Lapakko, K.A. Evaluation of neutralization potential determinations for metal mine waste and a proposed alternative. In Proceedings of the Third International Conference on the Abatement of Acidic Drainage, Pittsburgh, PA, USA, 24-29 April 1994.

73. Benzaazoua, M.; Bussière, B.; Dagenais, A. Comparison of kinetic tests for sulfide mine tailings. In Proceedings of the Tailings and Mine Waste 01, Fort Collins, CO, USA, 6-19 January 2001; Balkema: Fort Collins, CO, USA, 2001; pp. 263-272.

74. Benzaazoua, M.; Dagenais, A.-M.; Archambault, M. Kinetic tests comparison and interpretation for prediction of the Joutel tailings acid generation potential. Environ. Geol. 2004, 46, 1086-1101. [CrossRef]

75. Blowes, D.W.; Jambor, J.L.; Hanton-Fong, C.J.; Lortie, L.; Gould, W. Geochemical, mineralogical and microbiological characterization of a sulphide-bearing carbonate-rich gold-mine tailings impoundment, Joutel, Québec. Appl. Geochem. 1998, 13, 687-705. [CrossRef]

76. Bussière, B.; Benzaazoua, M.; Aubertin, M.; Mbonimpa, M. A laboratory study of covers made of low-sulphide tailings to prevent acid mine drainage. Environ. Geol. 2004, 45, 609-622. [CrossRef]

77. Caldeira, C.L.; Ciminelli, V.S.; Osseo-Asare, K. The role of carbonate ions in pyrite oxidation in aqueous systems. Geochim. Cosmochim. Acta 2010, 74, 1777-1789. [CrossRef]

78. Jamieson, H.E.; Walker, S.R.; Parsons, M.B. Mineralogical characterization of mine waste. Appl. Geochem. 2015, 57, 85-105. [CrossRef]

79. Nicholson, R.V.; Gillham, R.W.; Reardon, E.J. Pyrite oxidation in carbonate-buffered solution: 1. Experimental kinetics. Geochim. Cosmochim. Acta 1988, 52, 1077-1085. [CrossRef]

80. Coussy, S.; Benzaazoua, M.; Blanc, D.; Moszkowicz, P.; Bussière, B. Assessment of arsenic immobilization in synthetically prepared cemented paste backfill specimens. J. Environ. Manag. 2012, 93, 10-21. [CrossRef] [PubMed]

81. Elghali, A.; Benzaazoua, M.; Bouzahzah, H.; Bussière, B.; Villarraga-Gómez, H. Determination of the available acid-generating potential of waste rock, part I: Mineralogical approach. Appl. Geochem. 2018, 99, 31-41. [CrossRef]

82. Elghali, A.; Benzaazoua, M.; Bussière, B.; Bouzahzah, H. Determination of the available acid-generating potential of waste rock, part II: Waste management involvement. Appl. Geochem. 2019, 100, 316-325. [CrossRef]

83. Erguler, Z.A.; Erguler, G.K. The effect of particle size on acid mine drainage generation: Kinetic column tests. Miner. Eng. 2015, 76, 154-167. [CrossRef]

(C) 2019 by the authors. Licensee MDPI, Basel, Switzerland. This article is an open access article distributed under the terms and conditions of the Creative Commons Attribution (CC BY) license (http://creativecommons.org/licenses/by/4.0/). 